University of Nebraska - Lincoln

DigitalCommons@University of Nebraska - Lincoln

Roman L. Hruska U.S. Meat Animal Research

U.S. Department of Agriculture: Agricultural Center Research Service, Lincoln, Nebraska

2013

\title{
Isolation and Characterization of Clostridium difficile Associated with Beef Cattle and Commercially Produced Ground Beef
}

\author{
Norasak Kalchayanand \\ USDA Meat Animal Research Center, norasak.kalchayanand@ars.usda.gov \\ Terrance M. Arthur \\ USDA Meat Animal Research Center, terrance.arthur@ars.usda.gov \\ Joseph M. Bosilevac \\ USDA Meat Animal Research Center, mick.bosilevac@ars.usda.gov \\ Dayna M. Brichta-Harhay \\ USDA-ARS, dayna.harhay@ars.usda.gov \\ Steven D. Shackelford \\ USDA-ARS
}

See next page for additional authors

Follow this and additional works at: https://digitalcommons.unl.edu/hruskareports

Kalchayanand, Norasak; Arthur, Terrance M.; Bosilevac, Joseph M.; Brichta-Harhay, Dayna M.; Shackelford, Steven D.; Wells, James E.; Wheeler, Tommy L.; and Koohmaraie, Mohammad, "Isolation and Characterization of Clostridium difficile Associated with Beef Cattle and Commercially Produced Ground Beef" (2013). Roman L. Hruska U.S. Meat Animal Research Center. 395.

https://digitalcommons.unl.edu/hruskareports/395

This Article is brought to you for free and open access by the U.S. Department of Agriculture: Agricultural Research Service, Lincoln, Nebraska at DigitalCommons@University of Nebraska - Lincoln. It has been accepted for inclusion in Roman L. Hruska U.S. Meat Animal Research Center by an authorized administrator of DigitalCommons@University of Nebraska - Lincoln. 
Authors

Norasak Kalchayanand, Terrance M. Arthur, Joseph M. Bosilevac, Dayna M. Brichta-Harhay, Steven D.

Shackelford, James E. Wells, Tommy L. Wheeler, and Mohammad Koohmaraie

This article is available at DigitalCommons@University of Nebraska - Lincoln: https://digitalcommons.unl.edu/ hruskareports/395 


\title{
Isolation and Characterization of Clostridium difficile Associated with Beef Cattle and Commercially Produced Ground Beef
}

\author{
NORASAK KALCHAYANAND,* TERRANCE M. ARTHUR, JOSEPH M. BOSILEVAC, DAYNA M. BRICHTA-HARHAY, \\ STEVEN D. SHACKELFORD, JAMES E. WELLS, TOMMY L. WHEELER, AND MOHAMMAD KOOHMARAIE $\dagger,+$
}

\author{
U.S. Department of Agriculture, Agricultural Research Service, Roman L. Hruska U.S. Meat Animal Research Center, Clay Center, \\ Nebraska 68933-0166, USA
}

MS 12-261: Received 13 June 2012/Accepted 20 September 2012

\begin{abstract}
The incidence of Clostridium difficile infection has recently increased in North American and European countries. This pathogen has been isolated from retail pork, turkey, and beef products and reported associated with human illness. This increase in infections has been attributed to the emergence of a toxigenic strain designated North America pulsed-field gel electrophoresis type 1 (NAP1). The NAP1 strain has been isolated from calves as well as ground meat products, leading to speculation of illness from consumption of contaminated meat products. However, information on $C$. difficile associated with beef cattle during processing and commercially produced ground beef is limited. To address this data gap, samples from various steps during beef production were collected. Samples from hides $(n=525)$, preevisceration carcasses $(n=475)$, postintervention carcasses $(n=$ 471), and 956 commercial ground beef samples were collected from across the United States. The prevalence of $C$. difficile spores on hides was $3.2 \%$. C. difficile spores were not detected on preevisceration and postintervention carcasses or in commercially produced ground beef. Phenotypic and genetic characterizations were carried out for all 18 isolates collected from hide samples. Twenty-two percent of the isolates were nontoxigenic strains, while $78 \%$ of the isolates were toxigenic. Toxinotyping and PCR ribotyping patterns revealed that 6 and 33\% of the isolates were identified as NAP1 and NAP7 strains, respectively. This article evidences that the prevalence of $C$. difficile, specifically pathogenic strains, in the U.S. beef production chain is low.
\end{abstract}

Clostridium difficile is an obligate-anaerobic, grampositive, spore-forming bacillus bacterium. This organism is ubiquitous and has been isolated from the environment, animal feces, and feces of humans without diarrhea (9). The organism also has been identified as the etiologic agent causing $C$. difficile infections (CDI), with manifestations ranging from mild diarrhea to severe pseudomembranous colitis and even death (47). Severe CDI cases were reported throughout the United States, Canada, and several European countries $(29,53)$. The increase in severity of CDI was attributed to an emerging strain called North America pulsed-field gel electrophoresis type 1 (NAP1, also known as PCR ribotype 027). This strain is believed more virulent because of high production of toxins $A$ and $B$ (53). In addition to toxins TcdA and TcdB, which belong to the large clostridial toxins group, $C$. difficile strains also produce a third toxin, the cytolethal distending toxin (CDT), belonging to the group of clostridial binary toxins

\footnotetext{
* Author for correspondence. Tel: 402-762-4224; Fax: 402-762-4149; E-mail: norasak.kalchayanand@ars.usda.gov.

$\dagger$ Present address: IEH Laboratories and Consulting Group, 15300 Bothell Way N.E., Lake Forest Park, WA 98155, USA.

\$ Mention of trade names or commercial products in this article is solely for the purpose of providing specific information and does not imply recommendation or endorsement by the U.S. Department of Agriculture. The USDA is an equal opportunity provider and employer.
}

(35). Binary toxin can be produced by some strains that are TcdA and TcdB negative $\left(\mathrm{A}^{-} \mathrm{B}^{-}\right.$, toxinotype $\left.\mathrm{XI}\right)$; therefore, detection of binary toxin in some nontoxinogenic strains isolated from symptomatic patients reveals their virulence (43). The Centers for Disease Control and Prevention (CDC) stated that CDI cases in the United States have increased from 31 per 100,000 people in 1996 to 61 per 100,000 in 2003 (31).

Clostridial species associated with spoilage of vacuumpackaged refrigerated fresh and roasted beef was reported 20 years ago $(26,27)$. Although $C$. difficile ribotypes 078 and 027, which are commonly encountered in human outbreaks of CDI, no epidemiologic connection between human CDI and the foodborne illnesses were reported (19, 38). The manifestation of illnesses from Clostridium species is because of their toxins such as botulin from $C$. botulinum and an enterotoxin of $C$. perfringens (12). Disease caused by $C$. difficile is because of proliferation of the pathogen and release of toxins in the colonic mucosa when the normal flora of the colon has been interrupted or compromised (47). Toxin A has been described as an enterotoxin causing enteric fluid accumulation and diarrhea, while toxin $\mathrm{B}$ is a potent cytotoxin causing mucosal deterioration (7). $C$. difficile has been isolated from food and domestic animals, with a rate ranging widely, from 0 to $42 \%(5,11,17-21,24,32,33,37,38,44,48,52)$. The 
NAP1 strain (or PCR ribotype 027) has been isolated from calf feces as well as retail ground beef $(36,44)$. The strain NAP7 (or PCR ribotype 078) was also isolated from samples of retail pork, turkey, and beef products (44) and is associated with human illness (23). The isolation of these pathogenic strains from meat animals and retail meat products has led to speculation that CDI can result from foodborne transmission through the consumption of contaminated meat. However, all of the above-cited studies either isolated $C$. difficile from animal feces or from retail meat products. To the best of our knowledge, there is no information regarding $C$. difficile prevalence along the beef production chain in the United States. Therefore, the objectives of this study were to determine the prevalence of $C$. difficile from beef cattle during various stages of processing and in commercially produced ground beef, and to characterize the isolates for comparison to human outbreak strains.

\section{MATERIALS AND METHODS}

Bacterial strains and growth conditions. The reference strains of $C$. difficile ATTC 9689, ATCC 43594, Clostridium sordellii ATCC 9714, and Clostridium bifermentans ATCC 19299 were obtained from the American Type Culture Collection (Manassas, VA), and $C$. difficile NAP1 and NAP7 strains were obtained from the CDC. The $C$. difficile cultures were used as positive controls, whereas the $C$. sordellii and $C$. bifermentans were used as negative controls. All strains were grown anaerobically (Anaero Pack System, Mitsubishi Gas Chemical Co. Inc., New York) at $37^{\circ} \mathrm{C}$ for 24 to $48 \mathrm{~h}$ in Schaedler anaerobic broth (Accumedia Manufacturers, Inc., Lansing, MI).

In-plant sampling. Samples were collected at five different cull cow and/or fed-cattle processing plants (designated as plants A through E) throughout the United States between December 2006 and January 2007. Samples were collected on the process line at three different processing stages: hide, preevisceration carcass, and postintervention carcass, by using premoistened Speci-Sponges (Nasco, Fort Atkinson, WI) with sterile buffered-peptone water (BD, Franklin Lakes, NJ). Individual carcasses were tagged and tracked throughout the process. Ninety-six sponge samples were collected at each processing stage at every plant except for plants $\mathrm{D}$ and $\mathrm{E}$, where 192 and 50 sponge samples were collected, respectively. At plant E, only hide samples were collected.

Hide samples were collected after exsanguination from an area of approximately $0.1 \mathrm{~m}^{2}$ on the brisket by using a sponge premoistened with $20-\mathrm{ml}$ of sterile buffered-peptone water. Samples were collected by swabbing five times in a vertical direction on one side of the sponge and five times in a horizontal direction on the other side of sponge (3). For preevisceration and postintervention carcasses, two sponges premoistened each with $10 \mathrm{ml}$ of sterile buffered-peptone water were used to sample a total area of approximately $0.8 \mathrm{~m}^{2}$. Preevisceration carcass samples were collected immediately after hide removal on the leading side of the carcass by using one sponge for the inside and outside round $\left(\sim 0.4 \mathrm{~m}^{2}\right)$ and the second sponge for the navel-plate-brisketforeshank area $\left(\sim 0.4 \mathrm{~m}^{2}\right)$ (3). Postintervention carcass samples were collected as described for the preevisceration carcass but on the trailing carcass side of the same carcass when the carcass entered the cooler. All sample bags were transported overnight on ice to the laboratory. The two sponge samples from preevisceration and postintervention carcasses, respectively, were combined into one sample bag before microbiological processing to make one preevisceration sample and one postintervention sample per carcass. A total of 1,471 samples were analyzed for the prevalence of $C$. difficile spores.

Isolation of $C$. difficile spore from processing plant samples. Hide, preevisceration carcass, and postintervention carcass sponge samples were homogenized by hand massage, and for each sample, $1 \mathrm{ml}$ of solution was transferred into a $2-\mathrm{ml}$ sterile polypropylene tube (Biotube System, Simport, Beloeil, Quebec, Canada). One of the cluster tubes was inoculated with approximately 100 spores of $C$. difficile as a positive control to verify the isolation process. The present study used a method for spore isolation described previously $(27,38)$. A 1-ml aliquot of absolute ethanol was mixed into a cluster tube containing sponge homogenate, and the tube was shaken for $30 \mathrm{~min}$ at room temperature. A 50- $\mu$ l aliquot of alcohol-treated homogenate that was streaked on $C$. difficile selective medium (CDMN) was slightly modified from that previously described (4). In brief, the Columbia blood agar base was supplemented with $5 \mathrm{~g}$ of yeast extract per liter (BD), $6 \mathrm{~g}$ of fructose per liter (Sigma, St. Louis, MO), $1 \mathrm{~g}$ of $p$-hydroxyphenylacetic acid per liter, $0.5 \mathrm{~g}$ of L-cysteine $\mathrm{HCl}$ per liter, $5 \mathrm{mg}$ of hemin per liter, $10 \mathrm{mg}$ of vitamin $\mathrm{K}_{1}$ per liter, $1.0 \mathrm{~g} / \mathrm{liter}$ sodium taurocholate (Sigma), $32 \mathrm{mg}$ of moxalactam per liter, $12 \mathrm{mg}$ of norfloxacin per liter (Sigma), and $50 \mathrm{ml}$ of defibrinated horse blood per liter (Hardy Diagnostics, Santa Maria, CA). A 1-ml aliquot of alcohol-treated homogenate was anaerobically enriched with $9 \mathrm{ml}$ of CDMN broth containing $1 \mathrm{~g} /$ liter sodium taurocholate (Sigma) at $37^{\circ} \mathrm{C}$ for 10 to 15 days before streaking for isolation with a CDMN agar plate. The plate was incubated at $37^{\circ} \mathrm{C}$ for up to 5 days under anaerobic conditions by using the Anaero Pack System. The presumptive colonies were phenotypically and genotypically characterized relative to known C. difficile strains.

For each hide, preevisceration carcass, and postintervention carcass, prevalence of $C$. difficile spores was calculated by dividing the number of positive samples by the total of number of samples. In order to test for sample site prevalence differences, the DIFFER procedure of PEPI software (USD, Inc., Stone Mountain, GA) (13) was used to calculate the pairwise difference among processing stages, with the probability level at $P \leq 0.05$.

Ground beef. Participating commercial ground beef producers collected ground beef samples in the form of patties or chubs, with various percentages of lean meat $(73,80,85$, and $90 \%)$. The producers were organized according to the eight microbiological monitoring regions as defined by the Beef Industry Food Safety Council (BIFSCo) (Fig. 1). Ground beef samples were collected from seven of BIFSCo regions (the exception being region 4: Montana, Wyoming, Utah, and Colorado). Each sample was placed in a Whirl-Pak bag (Nasco) and frozen at $-20^{\circ} \mathrm{C}$ for up to 45 days. Approximately once a month, the frozen ground beef samples were shipped to the U.S. Meat Animal Research Center via an independent third party, which removed plant-specific information, except for region and collection date. On receipt, the samples were held at $-20^{\circ} \mathrm{C}$ for up to 15 more days before processing. A total of 956 ground beef samples were collected in 2007 from March to July and analyzed for the prevalence of $C$. difficile spores.

Isolation of $\boldsymbol{C}$. difficile spore from ground beef. Commercially produced ground beef samples were thawed at $4^{\circ} \mathrm{C}$. Each ground beef sample was weighed to $1 \pm 0.1 \mathrm{~g}$ and placed into a 10 -ml cluster tube containing $9 \mathrm{ml}$ of CDMN broth, as described above. One of the tubes was inoculated with approximately 100 


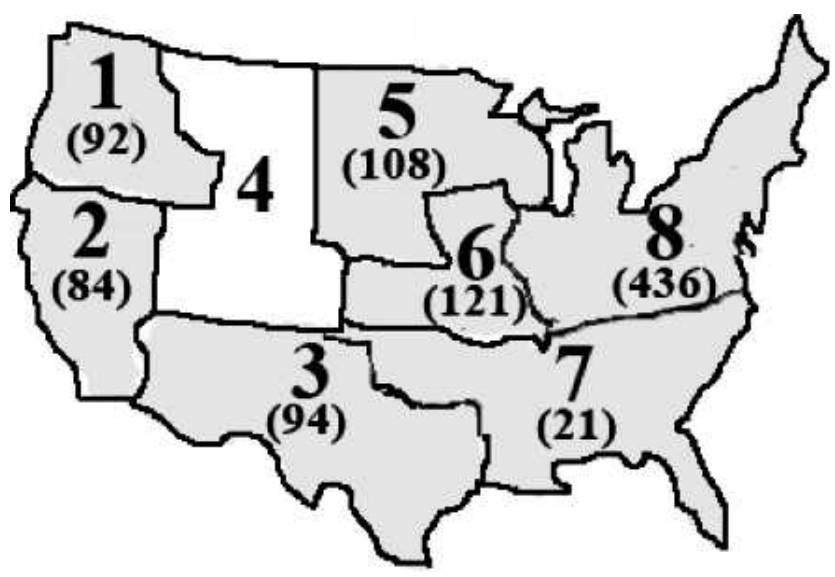

FIGURE 1. The Beef Industry Food Safety Council (BIFSCo) defines eight microbiological monitoring regions. Ground beef samples were obtained from seven of eight regions (the exception being region 4) for this study. The number in parentheses is the number of samples received from commercial ground beef producers in that region.

spores of $C$. difficile to serve as a positive control. The tube was incubated anaerobically at $37^{\circ} \mathrm{C}$ for 15 days. The alcohol treatment was performed as described above before streaking for isolation onto CDMN agar. The plate was incubated anaerobically at $37^{\circ} \mathrm{C}$ for 5 days.

Phenotypic characterization. Swarming, rough, and nonhemolytic colonies were subcultured on CDMN agar. The plate was examined under long-wavelength UV light $(365 \mathrm{~nm})$ for yellowish green fluorescent colonies. The growth of $C$. difficile produces a unique odor of horse manure (9), which was enhanced in this study because of $p$-cresol production on medium containing $p$-hydroxyphenylacetic acid (36). The absence of lecithinase activity was detected by streaking presumptive colonies on CDMN supplemented with $80 \mathrm{ml}$ of egg yolk emulsion per liter (BD), without horse blood. The L-proline aminopeptidase activity was determined with Pro Disk (Remel, Lenexa, KS). To finish, the presumptive colonies were confirmed by identification of the housekeeping gene tpi (28).

The MICs of several antibiotics for the isolates were determined with the Sensititre Anaerobe MIC susceptibility plate (Trek Diagnostic Systems, Cleveland, OH). MICs were set up according to the manufacturer's directions. The MIC plates were incubated anaerobically at $37^{\circ} \mathrm{C}$ for $48 \mathrm{~h}$ before the results were read with the Sensititre manual viewer.

Genotypic characterization. Each isolate was grown in Schaedler anaerobic broth for $18 \mathrm{~h}$, and DNA was extracted from $2 \mathrm{ml}$ of each culture by using the QIAamp DNA mini kit (QIAGEN, Inc., Valencia, CA) by following the manufacturer's recommendations. DNA was stored at $-20^{\circ} \mathrm{C}$ as a template for further analyses.

The detection of toxin $\mathrm{A}(t c d A)$ and toxin $\mathrm{B}(t c d B)$ genes was performed as described previously $(28,40)$. The presence and deletion of the $t c d C$ gene was determined with methods also described previously (45). The presence of the genes $c d t A$ and $c d t B$, which encode for binary toxin and toxinotyping of the isolates, was determined based on the protocol described by Stubbs et al. (46) and Rupnik et al. (39), respectively.

The PCR ribotyping of the isolates compared with the reference strains was performed as described previously (6). In brief, the amplification reaction of extracted DNA from each isolate was carried out in a $100-\mu \mathrm{l}$ volume containing $10 \mathrm{mM}$ Tris-HCl (pH 8.8; Sigma), $50 \mathrm{mM} \mathrm{KCl}, 1.5 \mathrm{mM} \mathrm{MgCl} 2,200 \mu \mathrm{M}$ each deoxynucleoside triphosphate, 50 pmol each primer (6), $2.5 \mathrm{U}$ of Taq polymerase (Promega, Madison, WI), and $10 \mu \mathrm{l}$ of DNA extract. Amplification was performed with an Eppendorf thermal cycler (Brinkmann Instruments, Westbury, NY) for 1 cycle of $6 \mathrm{~min}$ at $94^{\circ} \mathrm{C}$ for denaturation and 35 cycles of the following: $1 \mathrm{~min}$ at $94^{\circ} \mathrm{C}, 1 \mathrm{~min}$ at $57^{\circ} \mathrm{C}$, and $1 \mathrm{~min}$ at $72^{\circ} \mathrm{C}$, and a final extension of $7 \mathrm{~min}$ at $72^{\circ} \mathrm{C}$. C. difficile strains NAP1 and NAP7 (from the CDC) were used as the reference controls. The amplified products were run for $6 \mathrm{~h}$ at $85 \mathrm{~V}$ in sodium borate buffer (Faster Better Media, L.L.C., Hunt Valley, MD) by using electrophoresis through $2 \%$ agarose, type II medium EEO (Sigma). After electrophoresis, the gel was stained for $15 \mathrm{~min}$ in distilled water containing $0.5 \mu \mathrm{g}$ of ethidium bromide per $\mathrm{ml}$, and the DNA bands were visualized under UV illumination. The gel image was captured with the Gel Logic Imaging system (Eastman Kodak Co., Rochester, NY) and analyzed with BioNumerics 4.6 software (Applied Maths, Inc., Austin, TX) to perform dendrographic analysis of the ribotyping results. All software identified bands, and dendrographic pairs were confirmed visually.

\section{RESULTS AND DISCUSSION}

C. difficile spores were detected in $17(3.2 \%)$ of the 525 hide samples (Table 1). To our knowledge, our study is the first to report the prevalence of $C$. difficile during cattle processing. Most of the previous studies reported the prevalence of $C$. difficile in feces of food animals, but not during processing. Fecal prevalence of $C$. difficile has been reported at the rate of $6.3 \%$ in beef cows-calves (50), $11.4 \%$ in swine (51), $1.0 \%$ in sheep (2), and $12.5 \%$ in chickens (18). C. difficile spores were not detected on either preevisceration or postintervention carcasses (Table 1). Similarly, $C$. difficile was not isolated from samples of preevisceration and postintervention carcasses of veal calves (21). $C$. difficile is a spore-forming, obligate anaerobe and does not compete well with other background bacteria (25). If spores had an opportunity to vegetate on carcasses, then $C$. difficile could have been present but not detected, because vegetative forms do not tolerate exposure to air and do not compete with background flora. Therefore, the isolation technique used was based on the presence of $C$. difficile spores to remove other vegetative competitions.

None of the 956 commercially produced ground beef samples had detectable $C$. difficile spores (Table 1). It was shown by Weese et al. (54) that $C$. difficile contamination of meat such as pork tends to be at quite a low level. Beef carcass contamination with $C$. difficile, however, is not known and could also occur at a low level. The prevalence of $C$. difficile from commercially produced ground beef was possibly underestimated, as $1 \mathrm{~g}$ of ground beef sample was used for enrichment, which would reduce detection if lowlevel contamination was present in the starting materials. A subset of 100 commercially produced ground beef samples was tested with $5 \mathrm{~g}$ of each sample and $20 \mathrm{ml}$ of CDMN broth containing $0.1 \%$ sodium taurocholate. $C$. difficile was not detected from these larger sample enrichments nor was the housekeeping gene tpi detected by the enrichment of these samples (data not shown). In contrast, several studies reported detecting $C$. difficile in retail ground beef and meat products, where the isolation of $C$. difficile has ranged 
TABLE 1. Prevalence of Clostridium difficile in U.S. beef cattle during processing

\begin{tabular}{lcc}
\hline \multicolumn{1}{c}{ Sample type } & $n$ & Prevalence of $C$. difficile $(\%)^{a}$ \\
\hline Hide & 525 & $17(3.2) \mathrm{A}^{b}$ \\
Preevisceration carcass & 475 & $0(0) \mathrm{B}$ \\
Postintervention carcass & 471 & $0(0) \mathrm{B}$ \\
Ground beef $^{c}$ & 956 & $0(0)$ \\
\hline
\end{tabular}

${ }^{a}$ Prevalence values given are the number of positive samples with percentages given in parentheses.

${ }^{b}$ Means in this column bearing a common letter do not differ significantly at $P \leq 0.05$.

${ }^{c}$ The ground beef samples were not corresponded with hide and carcass samples collected and could not be analyzed together.

between 2.4 and $50 \%$ from ground beef, $14.3 \%$ from ground veal, $42.9 \%$ from ground pork, and $44.4 \%$ from ground turkey samples $(8,30,38,44)$. In the present study, $C$. difficile was not detected from commercially produced ground beef. However, the samples in previous studies were collected from retail store shelves, with little description of the samples or packaging. Typically, the largest volumes of commercially produced ground meat that are distributed to retail stores are in coarsely ground form and are packaged in 10 - to $25-\mathrm{lb}(4.5-$ to $11.3-\mathrm{kg})$ chubs. At the retail store, coarsely ground meat chubs are subjected to regrinding, repackaging, and sold as retail ground beef. During this processing at retail stores, postcontamination with spores of $C$. difficile can occur from the environment, because bacterial spores are ubiquitous and are not destroyed by sanitizers. In the present study, the ground beef came directly from processors, not retail outlets. Our study did not detect $C$. difficile on carcasses or ground beef received directly from processors. This is consistent with the speculation that previous studies found $C$. difficile in retail ground meat samples because of cross-contamination from other sources $(38,21)$.

Previous studies reported that the fecal prevalence of $C$. difficile is high in swine (51) and poultry (18) compared with beef cattle (50). It is well documented that fecalcontaminated hides are the major source of carcass contamination (22). Differences in processing procedures could lead to more $C$. difficile contamination. For example, both swine and poultry plants use heat treatments to remove hair and feathers, respectively, from carcasses. Heat treatments can potentially activate spores of $C$. difficile as well as kill off competing flora, thereby increasing carcass contamination. An activated spore possesses an exosporial membrane (34), which allows closer attachment to meat surfaces, thus making carcass decontamination more difficult. Therefore, prevalence determination of $C$. difficile should not focus only on beef cattle production, but also on pork and poultry production.

In samples collected at beef processing plants, a total of 18 isolates were recovered from 17 positive hide samples (Table 2). The rate of recovery of isolates from each hide sampled was very low. The agar plate had a single presumptive colony for each hide sample, except one sample from processing plant $\mathrm{E}$, which had two presumptive colonies. All 18 isolates produced yellowish green fluorescence under UV illumination, had $p$-cresol odor, were Lproline aminopeptidase reactive, were negative for both indole and lecithinase reactions (data not shown), and had the tpi gene as compared with positive and negative controls (Table 2).

The detection of $C$. difficile toxins A and B in feces of humans with diarrhea is considered diagnostic for CDI (1, 55). However, the biochemical characterizations could not differentiate the $C$. difficile from hides from the CDI reference strains. Therefore, the isolate genotypes were characterized for their toxin genes and compared with the NAP1 and NAP7 strains (Table 2), which carry both $t c d A$ and $t c d B$. Of 18 isolates, $3(16.7 \%)$ isolates did not carry either gene $t c d A$ or $t c d B$, and $14(77.8 \%)$ isolates carried both genes. One isolate $(\mathrm{C} 1)$ was very unusual; it carried the $t c d A$ gene but not the $t c d B$ gene. The designation $t c d A^{+} B^{-}$ of this strain (Table 2) was based on the presence of fragments $\mathrm{A} 2$ and $\mathrm{A} 3$ of the $t c d A$ gene, but not B1, B2, and B3 of the $t c d B$ (data not shown), as described by Rupnik et al. (41). The patterns of amplified B1 and A3 fragments that were cut with restriction enzymes (AccI and HincII for the B1 fragment, and EcoRI for the A3 fragment) designated this isolate as toxinotype XIa (Table 2). Because the toxinotypes XI (a and b) do not express detectable levels of toxins $\mathrm{A}$ or $\mathrm{B}(40)$, this toxinotype is not a true $\mathrm{A}^{+} \mathrm{B}^{-}$ strain. A similar strain of $t c d A^{+} B^{-}$also was isolated from a recurrent $\mathrm{CDI}$, as described by Cohen et al. (10).

The $t c d C$ gene, located within the pathogenicity locus (PaLoc), regulates the expression of $t c d A$ and $t c d B$ (46). In this study, 15 isolates carried the $t c d C$ gene, both with and without deletions. Nine isolates had $t c d C$ without deletions, and six isolates had $t c d C$ with 39-bp deletions. In addition to toxins $\mathrm{A}$ and $\mathrm{B}$, some strains of $C$. difficile also produce a third toxin, binary toxin CDT, which is encoded by the genes $c d t A$ and $c d t B$, located outside PaLoc (42). However, the role of binary toxin CDT in disease, as well as its relationship to toxins $\mathrm{A}$ and $\mathrm{B}$, is unknown (14). Of 18 isolates, $9(50 \%)$ isolates carried binary toxin CDT genes (Table 2), which is much higher than the $6 \%$ reported in previous studies $(15,16,46)$.

Toxinotyping of the 18 hide isolates revealed seven toxinotypes (Table 2). One (6\%) isolate each from plants A, $\mathrm{C}$, and D was identified as toxinotype XV, XIa, and XII, respectively. Two (12\%) isolates, one from plant $\mathrm{D}$ and the other from plant E, were identified as toxinotype 0 . All three (18\%) isolates from plant D were toxinotype II. One $(6 \%)$ isolate from plant D was identified as toxinotype III, which was the same as reference strain NAP1. Six (33\%) isolates, two from plant D and four from plant E, were toxinotype V, corresponding to the reference strain NAP7 and were the toxinotype isolated most frequently from cattle hides. Hide isolates from plant $\mathrm{D}$ were classified into multiple toxinotypes, while hide isolates from plant E were clustered with toxinotype $\mathrm{V}$. Although the present study did not attempt to determine regional distribution of $C$. difficile, the diversity of the toxinotypes implies regional variation. In the United States, the recoveries of $C$. difficile from 2,965 fecal samples from cattle operations representing different regions 
TABLE 2. Genotypical characteristics of Clostridium difficile strains isolated from cattle hides

\begin{tabular}{|c|c|c|c|c|c|c|c|c|c|}
\hline \multirow[b]{2}{*}{ Plant or Clostridium strain ${ }^{a}$} & \multirow[b]{2}{*}{$n$} & \multirow[b]{2}{*}{ Isolate } & \multicolumn{6}{|c|}{ Gene identification $^{b}$} & \multirow[b]{2}{*}{ Toxinotype $^{c}$} \\
\hline & & & tpi & $t c d A$ & $t c d B$ & $t c d C(\mathrm{bp})^{d}$ & $c d t A$ & $c d t B$ & \\
\hline A & 95 & A1 & + & + & + & + & + & + & XV \\
\hline B & 95 & None & & & & & & & \\
\hline $\mathrm{C}$ & 95 & $\mathrm{C} 1^{e}$ & + & + & - & + & + & + & XIa \\
\hline \multirow[t]{8}{*}{$\mathrm{D}$} & 190 & D1 & + & + & + & + & - & - & II \\
\hline & & D2 & + & + & + & + & - & - & 0 \\
\hline & & D3 & + & + & + & $+(39)$ & + & + & $\mathrm{V}$ \\
\hline & & D4 & + & + & + & + & - & - & XII \\
\hline & & D5 & + & + & + & + & - & - & II \\
\hline & & D6 & + & + & + & + & - & - & II \\
\hline & & D7 & + & + & + & + & + & + & III \\
\hline & & D8 & + & + & + & $+(39)$ & + & + & $\mathrm{V}$ \\
\hline \multirow[t]{8}{*}{$\mathrm{E}$} & 50 & E1 & + & + & + & $+(39)$ & + & + & $\mathrm{V}$ \\
\hline & & E2 & + & + & + & $+(39)$ & + & + & $\mathrm{V}$ \\
\hline & & E3-1 & + & - & - & - & - & - & \\
\hline & & E3-2 & + & + & + & + & - & - & 0 \\
\hline & & E4 & + & + & + & $+(39)$ & + & + & $\mathrm{V}$ \\
\hline & & E5 & + & - & - & - & - & - & \\
\hline & & E6 & + & + & + & $+(39)$ & + & + & V \\
\hline & & E7 & + & - & - & - & - & - & \\
\hline difficile ATCC 9689 & & & + & + & + & + & - & - & $\mathrm{ND}^{f}$ \\
\hline difficile ATCC 43593 & & & + & - & - & - & - & - & ND \\
\hline difficile NAP-1 & & & + & + & + & $+(18)$ & + & + & III \\
\hline difficile NAP-7 & & & + & + & + & $+(39)$ & + & + & $\mathrm{V}$ \\
\hline sordellii ATCC 9714 & & & - & - & - & ND & - & - & ND \\
\hline \multicolumn{10}{|l|}{ bifermentans ATCC } \\
\hline 19299 & & & - & - & - & ND & ND & ND & ND \\
\hline
\end{tabular}

${ }^{a}$ C. difficile ATCC 9689, 43593, NAP1, and NAP7 were used as positive controls, while C. sordellii and $C$. bifermentans were used as negative controls.

${ }^{b} t p i$, triose-phosphate isomerase gene; $t c d A$ and $t c d B$, genes associated with toxins A and B (respectively) production; $t c d C$, negative regulator gene of $t c d A$ and $t c d B ; c d t A$ and $c d t B$, binary toxins $\mathrm{A}$ and $\mathrm{B}$ (respectively).

${ }^{c}$ Toxinotyping was based on the patterns of amplified B1 and A3 fragments that were cut with restriction enzymes (AccI and HincII for the B1 fragmant and EcoRI for the A3 fragment) according to the methods of Rupnik et al. (39).

${ }^{d}$ The number in parentheses is the base pair (bp) deletion in the $t c d C$ gene.

${ }^{e}$ The designation $t c d A^{+} B^{-}$of $\mathrm{C} 1$ strain was based on the presence of fragments $\mathrm{A} 2$ and $\mathrm{A} 3$ of the $t c d A$ gene, but not B1, B2, and B3 of the $t c d B$ gene.

${ }^{f} \mathrm{ND}$, not determined.

were reported as 9.8, 4.3, and $2.5 \%$ for Southeastern, Central, and Western regions, respectively (50). However, sale and transportation of beef trimmings around the country for ground beef production could mean regional differences occurred by chance.

The antibiotic susceptibility and resistance of $C$. difficile isolates are shown in Table 3. Most of the isolates were susceptible to at least 11 of the 15 antibiotics tested. All 18 isolates were resistant to cefoxitin, and 11 isolates were multidrug resistant (to two or more antibiotics). Only one isolate was resistant to four antibiotics (imipenem, clindamycin, cefoxitin, and tetracycline). Six (33\%) isolates were resistant to clindamycin, but none of the isolates were resistant to metronidazole. Clindamycin and metronidazole are important; they are the drugs of choice for the treatment of infections caused by anaerobic bacteria, especially clindamycin, which is used in the treatment of CDI (49). The results from this study suggest that C. difficile from human isolates is more resistant to clindamycin and metronidazole than the isolates from beef cattle hides.

Songer et al. (44) reported that $42 \%$ of retail meat products contained the toxigenic $C$. difficile strains NAP1 (or NAP1 related) and NAP7. In the present study, both NAP1 (toxinotype III) and NAP7 (toxinotype V) strains were isolated from cattle hides, but at lower prevalence rates. All 18 isolates from cattle hides were PCR ribotyped as previously described (6) by using strains NAP1 and NAP7 as reference standards. The PCR ribotyping results and the dendrogram of the isolates compared with the reference strains are shown in Figure 2. Electrophoresis yielded major banding patterns of between four and eight fragments. With BioNumerics software, the hide isolates' banding patterns and the banding patterns of reference strains were compared. Nine different PCR ribotypes were observed among the hide isolates. The dendrogram revealed genomic diversity, with similarity coefficients ranging from 50 to $100 \%$. There were four different PCR ribotypes that 


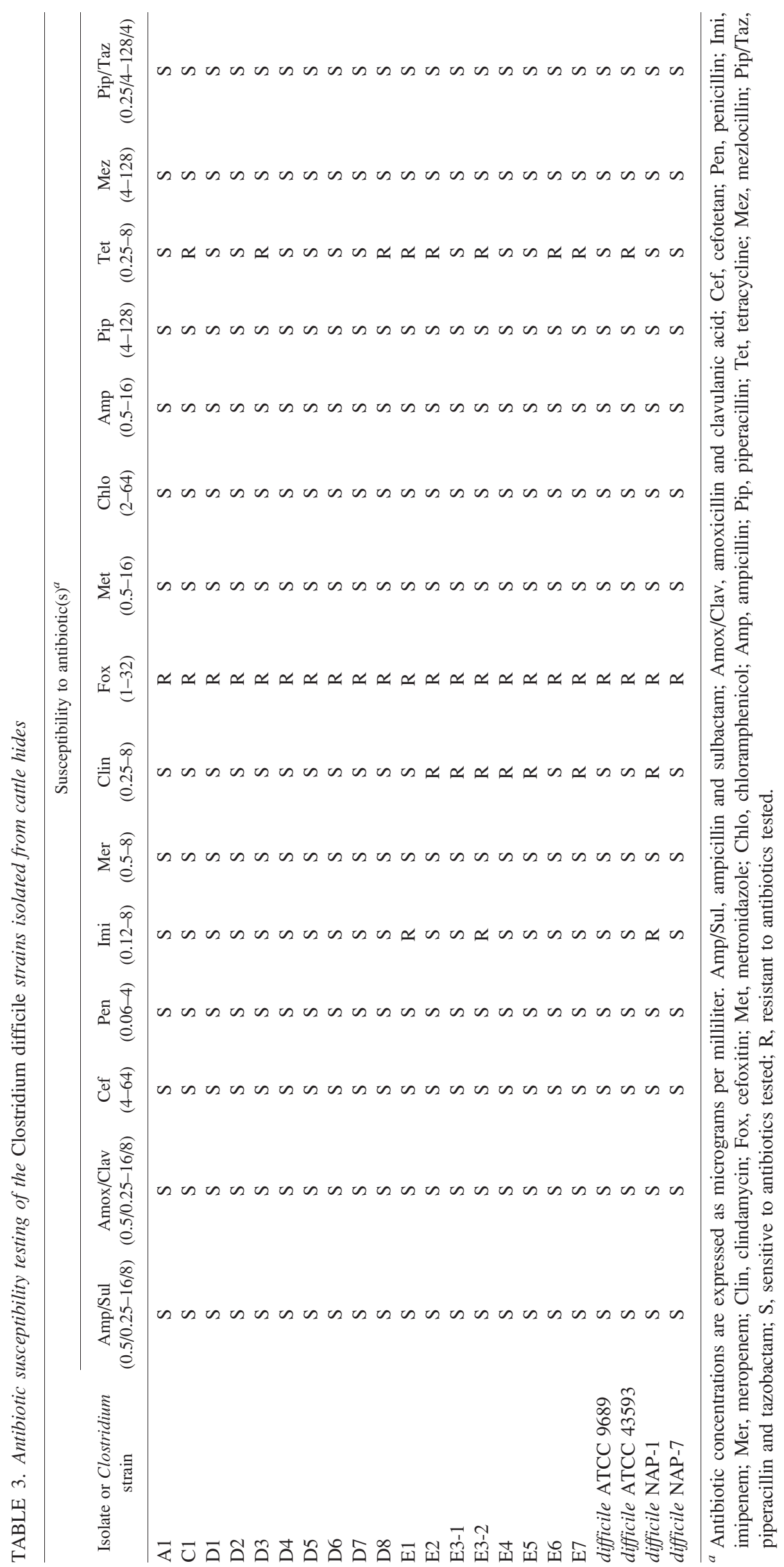


FIGURE 2. PCR ribotyping results and dendrographic analysis of the hide isolates and reference strains are shown in the vertical axis. The scale bar indicates the percent similarities.

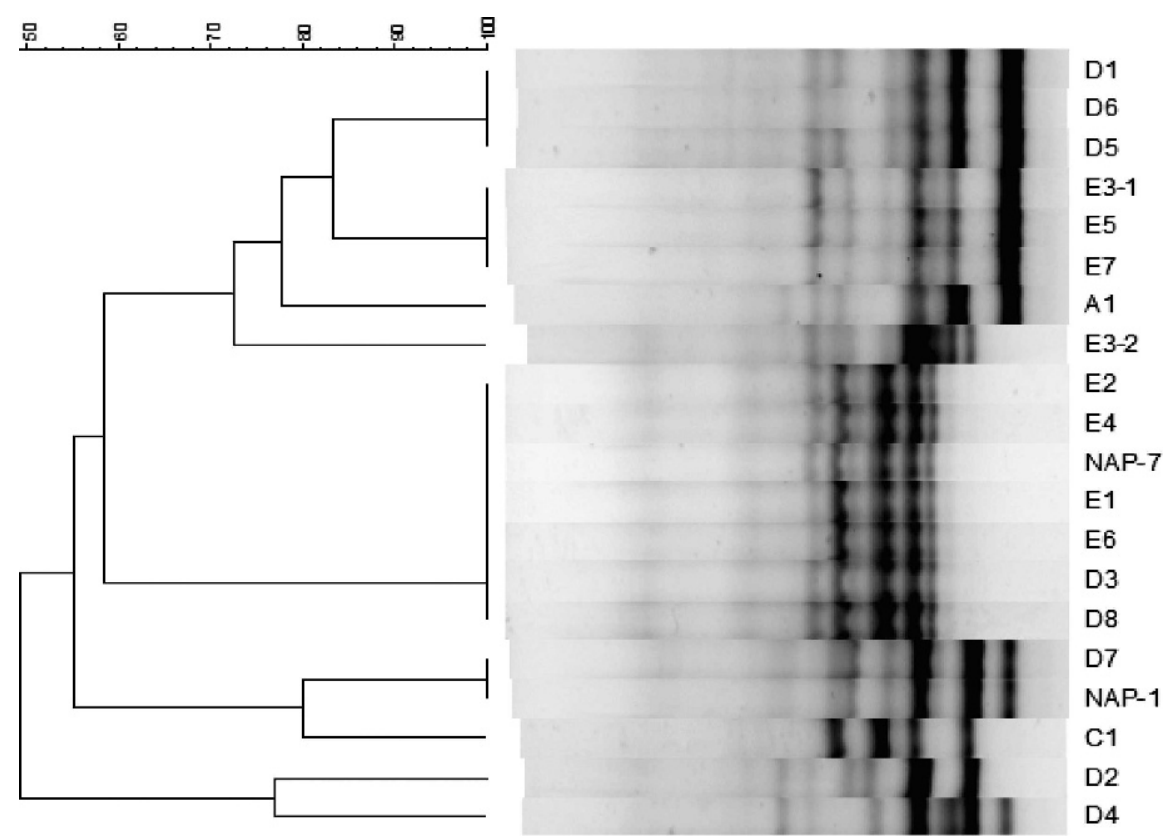

showed similarity among the isolates. Two PCR ribotypes showed similarity of the band patterns within their processing plant source (isolates D1, D5, and D6 and E31, E5, and E7). There were two PCR ribotyping patterns that showed similarity to NAP1 (toxinotype III) and NAP7 (toxinotype V). One (6\%) isolate, designated as D7, was indistinguishable from NAP1, but the $t c d C$ fragment lacked the 18-bp deletions (Table 2). Six (33\%) isolates-D3, D8, E1, E2, E4, and E6-were indistinguishable from NAP7, and all six strains had the 39-bp deletions in $t c d C$ (Table 2).

In summary, information on the prevalence of $C$. difficile associated with beef cattle during processing and in commercially produced ground beef is very limited. In this study, we sampled and tracked animals from five different processing plants before hide removal through the cooler and tested unrelated, commercially produced ground beef from across the United States. The results show that prevalence of $C$. difficile was found only on cattle hides. There was no $C$. difficile found on preevisceration carcasses, postintervention carcasses, or in commercially produced ground beef. The $C$. difficile isolates were characterized both phenotypically and genotypically and compared with reference strains. One and six of the isolates were identified as strains NAP1 (toxinotype III) and NAP7 (toxinotype V), respectively. Most of the isolates from beef cattle were sensitive to antibiotics commonly used in human therapy. Although a low percentage of cattle hides had pathogenic strains of $C$. difficile, the pathogen was not detected on beef carcasses or in ground beef, implying beef is unlikely a direct source of $C$. difficile.

\section{ACKNOWLEDGMENTS}

The authors thank Dr. Michael N. Guerini for his assistance with this research project; Drs. Clifford L. McDonald and Brandi Limbago for providing reference strains NAP1 and NAP7; Bruce Jasch, Frank Reno, Greg Smith, and Dee Kucera for their technical assistance; and Cheryl Yates and Jody Gallagher for their secretarial assistance. The authors also thank Drs. Ray A. Field, Xiangwu Nou, and Roger B. Harvey for their comments and suggestions of this manuscript.

\section{REFERENCES}

1. Alfa, M. J., T. Du, and G. Beda. 1998. Survey of incidence of Clostridium difficile infection in Canada hospitals and diagnostic approaches. J. Clin. Microbiol. 36:2076-2080.

2. Al Saif, N., and J. S. Brazier. 1996. The distribution of Clostridium difficile in the environment of South Wales. J. Med. Microbiol. 45: 133-137.

3. Arthur, T. M., J. M. Bosilevac, X. Nou, S. D. Shackelford, T. L. Wheeler, M. P. Kent, D. Jaroni, B. Pauling, D. M. Allen, and M. Koohmaraie. 2004. Escherichia coli O157:H7 prevalence and enumeration of aerobic bacteria, Enterobacteriaceae, and Escherichia coli $\mathrm{O} 157: \mathrm{H} 7$ at various steps in commercial beef processing plants. J. Food Prot. 67:658-665.

4. Aspinall, S. T., and D. N. Hutchinson. 1992. New selective medium for isolating Clostridium difficile from feces. J. Clin. Pathol. 45: 812-814.

5. Bakri, M. M., D. J. Brown, J. P. Butcher, and A. D. Sutherland. 2009. Clostridium difficile in ready-to-eat salads, Scotland. Emerg. Infect. Dis. 15:817-818.

6. Bidet, P., F. Barbut, V. Lalande, B. Burghoffer, and J. Petit. 1999. Development of a new PCR-ribotyping method for Clostridium difficile based on ribosomal RNA gene sequencing. FEMS Microbiol. Lett. 175:261-266.

7. Borriello, S. P., H. A. Davies, S. Kamiya, P. J. Reed, and S. Seddon. 1990. Virulence factors of Clostridium difficile. Rev. Infect. Dis. 12(Suppl.):S185-S191.

8. Bouttier, S., M. C. Barc, B. Felix, S. Lambert, A. Collignon, and F. Barbut. 2010. Clostridium difficile in ground meat, France. Emerg. Infect. Dis. 16:733-735.

9. Cato, E. P., W. L. George, and S. M. Finegold. 1986. Genus Clostridium, p. 1165-1166. In P. H. A. Sneath, N. S. Mair, and M. E. Sharpe (ed.), Bergey's manual of systematic bacteriology, vol. 2. Williams and Wilkins, Baltimore.

10. Cohen, S. H., Y. J. Tang, B. Hansen, and J. Silva, Jr. 1998. Isolation of a toxin B-deficient mutant strain of Clostridium difficile in a case of recurrent $C$. difficile-associated diarrhea. Clin. Infect. Dis. 26: 410-412.

11. de Boer, E., A. Zwartkruis-Nahuis, A. E. Heuvelink, C. Harmanus, and E. J. Kuijper. 2010. Prevalence of Clostridium difficile in retailed meat in The Netherlands. Int. J. Food Microbiol. 144:561-564. 
12. Finegold, S. M. 1977. Anaerobic bacteria in human disease. Academic Press, New York.

13. Fliess, J. L. (ed.). 1981. Statistical methods for rates and proportions, 2nd ed. John Wiley and Sons, New York.

14. Geric, B., R. J. Carman, M. Rupnik, C. W. Genheimer, S. P. Sambol, D. M. Lyerly, D. N. Gerding, and S. Johnson. 2006. Binary toxinproducing, large, clostridial toxin-negative Clostridium difficile strains are enterotoxic but do not cause disease in hamsters. J. Infect. Dis. 193:1143-1150.

15. Geric, B., M. Rupnik, D. N. Gerding, M. Grabnar, and S. Johnson. 2004. Distribution of Clostridium difficile variant toxinotypes and strains with binary toxin genes among clinical isolates in an American hospital. J. Med. Microbiol. 53:887-894.

16. Gonçalves, C., D. Decré, F. Barbut, B. Burghoffer, and J. C. Petit. 2004. Prevalence and characterization of a binary toxin (actin-specific ADP-ribosyltransferase) from Clostridium difficile. J. Clin. Microbiol. 42:1933-1939.

17. Gould, L. H., and B. Limbago. 2010. Clostridium difficile in food and domestic animals: a new foodborne pathogen? Clin. Infect. Dis. 51: 577-582.

18. Harvey, R. B., K. N. Norman, K. Andrews, M. E. Hume, C. M. Scanlan, T. R. Callaway, R. C. Anderson, and D. J. Nisbet. 2011. Clostridium difficile in poultry and poultry meat. Foodborne Pathog. Dis. 8:1321-1323.

19. Harvey, R. B., K. N. Norman, K. Andrews, B. Norby, M. E. Hume, C. M. Scanlan, M. D. Hardin, and H. M. Scott. 2011. Clostridium difficile in retail meat and processing plants in Texas. J. Vet. Diagn. Invest. 23:807-811.

20. Hoffer, E., H. Haechler, R. Frei, and R. Stephan. 2010. Low occurrence of Clostridium difficile in fecal samples of healthy calves and pigs at slaughter and in minced meat in Switzerland. J. Food Prot. 73:973-975.

21. Houser, B. A., M. K. Soehnlen, D. R. Wolfgang, H. R. Lysczek, C. M. Burns, and B. M. Jayarao. 2012. Prevalence of Clostridium difficile toxin genes in the feces of veal calves and incidence of ground veal contamination. Foodborne Pathog. Dis. 9:32-36.

22. International Commission on Microbiological Specifications for Foods. 2005. Microbiology of foods 6: microbial ecology of food commodities, 2nd ed. Kluwer Academic-Plenum Publishers, New York.

23. Jhung, M. A., A. D. Thompson, G. E. Killgore, W. E. Zukowski, J. G. Songer, M. Warny, S. Johnson, D. N. Gerding, L. C. McDonald, and B. M. Limbago. 2008. Toxinotype V Clostridium difficile in humans and food animals. Emerg. Infect. Dis. 14:1039-1045.

24. Jöbstl, M., S. Heuberger, A. Indra, R. Nepf, J. Kofer, and M. Wagner. 2010. Clostridium difficile in raw products of animal origin. Int. J. Food Microbiol. 138:172-175.

25. Jones, R. L. 1989. Diagnostic procedures for isolation and characterization of Clostridium difficile associated with enterocolitis in foals. J. Vet. Diagn. Invest. 1:84-86.

26. Kalchayanand, N., B. Ray, and R. A. Field. 1993. Characteristics of psychrotrophic Clostridium laramie causing spoilage of vacuumpackaged refrigerated fresh and roasted beef. J. Food Prot. 56:13-17.

27. Kalchayanand, N., B. Ray, R. A. Field, and M. C. Johnson. 1989. Spoilage of vacuum-packaged refrigerated beef by Clostridium. J. Food Prot. 52:424-426.

28. Lemee, L., A. Dhalluin, S. Testelin, M. A. Mattrat, K. Maillard, J. F. Lemeland, and J. L. Pons. 2004. Multiplex PCR targeting tpi (triosephosphate isomerase), $t c d A$ (toxin A), and $t c d B$ (toxin $\mathrm{B}$ ) genes for toxigenic culture of Clostridium difficile. J. Clin. Microbiol. 42: $5710-5714$.

29. Loo, V. G., L. Poirier, M. A. Miller, M. Oughton, M. D. Libman, S. Michaud, A. M. Bourgault, T. Nguyen, C. Frenette, M. Kelly, A. Vibien, P. Brassard, S. Fenn, K. Dewar, T. J. Hudson, R. Horn, P. Rene, Y. Monczak, and A. Dascal. 2005. A predominantly clonal multi-institutional outbreak of Clostridium difficile-associated diarrhea with high morbidity and mortality. N. Engl. J. Med. 353:2442-2449.

30. Martirani Von Abercron, S. M., F. Karlsson, G. T. Wigh, M. Wierup, and K. Krovacek. 2009. Low occurrence of Clostridium difficile in retail ground meat in Sweden. J. Food Prot. 72:1732-1734.
31. McDonald, L. C., M. Owings, and D. B. Jernigan. 2006. Clostridium difficile infection in patients discharged from U.S. short-stay hospitals, 1996-2003. Emerg. Infect. Dis. 12:409-415.

32. Metcalf, D., B. P. Avery, N. Janecko, N. Matic, R. Reid-Smith, and J. S. Weese. 2011. Clostridium difficile in seafood and fish. Anaerobe 17:85-86.

33. Metcalf, D., R. J. Reid-Smith, B. P. Avery, and J. S. Weese. 2010. Prevalence of Clostridium difficile in retail pork. Can. Vet. J. 51:873-876.

34. Panessa-Warren, B. J., G. T. Tortora, and J. B. Warren. 1997. Exosporial membrane plasticity of Clostridium sporogenes and Clostridium difficile. Tissue Cell 29:449-461.

35. Perelle, S., M. Gilbert, P. Bourlioux, G. Corthier, and M. R. Popoff. 1997. Production of a complete binary toxin (actin-specific ADPribosyltransferase) by Clostridium difficile CD196. Infect. Immun. 65: 1402-1407.

36. Phillips, K. D., and P. A. Roger. 1981. Rapid detection and presumptive identification of Clostridium difficile by $p$-cresol production on selective medium. J. Clin. Pathol. 34:642-644.

37. Rodriguez-Palacios, A., H. Stämpfli, T. Duffield, A. S. Peregrine, L. A. Trozt-Williams, L. G. Arroyo, J. S. Brazier, and S. Weese. 2006. Clostridium difficile PCR ribotypes in calves, Canada. Emerg. Infect. Dis. 12:1730-1736.

38. Rodriguez-Palacios, A., H. R. Stämpfli, T. Duffield, and J. S. Weese. 2007. Clostridium difficile in retail ground meat, Canada. Emerg. Infect. Dis. 13:485-487.

39. Rupnik, M., V. Avesani, M. Janc, C. V. Eichel-Streiber, and M. Delmée. 1998. A novel toxinotyping scheme and correlation of toxinotypes with serogroups of Clostridium difficile isolates. J. Clin. Microbiol. 36:2240-2247.

40. Rupnik, M., V. Braun, F. Soehn, M. Janc, M. Hofstetter, R. Laufenberg-Feldmann, and C. von Eichel-Streiber. 1997. Characterization of polymorphisms in the toxins A and B genes of Clostridium difficile. FEMS Microbiol. Lett. 148:197-202.

41. Rupnik, M., J. S. Brazier, B. I. Duerden, M. Grabnar, and S. L. J. Stubbs. 2001. Comparison of toxinotyping and PCR ribotyping of Clostridium difficile strains and description of novel toxinotypes. Microbiology 147:439-447.

42. Rupnik, M., B. Dupuy, N. F. Fairweather, D. N. Gerding, S. Johnson, I. Just, D. M. Lyerly, M. R. Popoff, J. I. Rood, A. L. Sonenshein, M. Thelestam, B. W. Wren, T. D. Wilkins, and C. von Eichel-Streiber. 2005. Revised nomenclature of Clostridium difficile toxins and associated genes. J. Med. Microbiol. 54:113-117.

43. Rupnik, M., M. Grabnar, and B. Geric. 2003. Binary toxin-producing Clostridium difficile strains. Anaerobe 9:289-294.

44. Songer, J. G., H. T. Trinh, G. E. Killgore, A. D. Thompson, L. C. McDonald, and B. M. Limbago. 2009. Clostridium difficile in retail meat products, USA, 2007. Emerg. Infect. Dis. 15:819-821.

45. Spigaglia, P., and P. Mastrantonio. 2002. Molecular analysis of the pathogenicity locus and polymorphism in the putative negative regulator of toxin production ( $\mathrm{TcdC})$ among Clostridium difficile clinical isolates. J. Clin. Microbiol. 40:3470-3475.

46. Stubbs, S., M. Rupnik, M. Gilbert, J. S. Brazier, B. Duerden, and M. Popolf. 2000. Production of actin-specific ADP-ribosyltranferase (binary toxin) by strains of Clostridium difficile. FEMS Microbiol. Lett. 286:307-312.

47. Sunenshine, R. H., and L. C. McDonald. 2007. Clostridium difficileassociated disease: new challenges from an established pathogen. Cleveland Clin. J. Med. 73:187-197.

48. Thean, S., B. Elliott, and T. V. Riley. 2011. Clostridium difficile in horses in Australia: a preliminary study. J. Med. Microbiol. 60:1188-1192.

49. Thomas, C., M. Stevenson, and T. V. Riley. 2003. Antibiotics and hospital-acquired Clostridium difficile-associated diarrhea: a systematic review. J. Antimicrob. Chemother. 51:1339-1350.

50. U.S. Department of Agriculture, Animal and Plant Health and Inspection Service. 2011. Clostridium difficile on U.S. beef cow-calf operations. U.S. Department of Agriculture, Animal and Plant Health and Inspection Service technical brief. Available at: http://nahms. aphis.usda.gov. Accessed 18 May 2012.

51. U.S. Department of Agriculture, Animal and Plant Health and Inspection Service. 2011. Clostridium difficile on U.S. swine 
operations. U.S. Department of Agriculture, Animal and Plant Health and Inspection Service technical brief. Available at: http://nahms. aphis.usda.gov. Accessed 12 September 2012.

52. von Abercron, S. M., F. Karlsson, G. T. Wigh, M. Wierup, and K. Krovacek. 2009. Low occurrence of Clostridium difficile in retail ground meat in Sweden. J. Food Prot. 72:1732-1734.

53. Warny, M., J. Pepin, A. Fang, G. Killgore, A. Thompson, J. Brazier, E. Frost, and L. C. McDonald. 2005. Toxin production by an emerging strain of Clostridium difficile associated with outbreaks of severe disease in North America and Europe. Lancet 366:10791084.

54. Weese, J. S., B. P. Avery, J. Rousseau, and R. J. Reid-Smith. 2009. Detection and enumeration of Clostridium difficile spores in retail beef and pork. Appl. Environ. Microbiol. 75:5009-5011.

55. Wilkins, T. D., and D. M. Lyerly. 2003. Clostridium difficile testing: after 20 years, still challenging. J. Clin. Microbiol. 41:531-534. 